\title{
Organizational Image and Attractiveness in the context of Recruitment: A conceptual review
}

\author{
Joseph R. Roche \\ Research Scholar, Department of OB \& HR, Alliance University, Alliance School of \\ Business, Chandapura-Anekal Main Road, Bengaluru, Karnataka State ZIP- 562106, India.
}

\begin{abstract}
In the recruitment literature the importance of organizational attractiveness and image has been studied over the last two decades demonstrating the relevance of this research in this field. From the review of literature, we find that there is no systematic literature review of organizational image and organizational attractiveness from various perspectives. This article aims to close this research gap. A systematic review of 36 articles in reputed journals provides a broad overview of the theoretical and empirical findings on organizational image and attractiveness. A systematic literature review adds value by synthesizing largely unconnected research from various disciplines and theoretical frameworks, which allows the creation of a common knowledge base for future research.
\end{abstract}

Keywords: Recruitment, Organizational attractiveness, Organizational Image, Corporate Image.

\section{Introduction}

Every organization has an image, whether planned or not. A good image can offer much to an organization's success (Gregory 1999). A favorable corporate image is an important resource as it provides organizations with a competitive advantage by stimulating potential candidates.

Organizational image is a source of information about a firm, which may be used to form perceptions and beliefs. Gooch (1999) believes that "image is everything" and Lewis (2001) says image is an asset of immense value that enable organizations to charge a premium for their products and services.

The concept of organizational image is multidisciplinary, covers disciplines such as Organizational behavior, Psychology, Marketing, Public Relations, Branding and Organizational communications. Organizations spend considerable resources in building a unique and distinct image using branding, communications as well a culture management to align the organizational behavior with the projected self-image.

Organizational attractiveness as an employer denotes "the envisioned benefits that a potential employee sees in working for a specific organization" (Berthon etal, 2005).

Bendaravičienè, Krištolaitis, \&Bakanauskienè (2011) refer to organizational attractivenes as "The power that draws applicants attention to focus on an employer brand and encourages existing employees to stay".

\section{Review of Literature}

Organizational image has been studied from very different perspectives and researchers from different backgrounds have attached very different meanings to the constructs. This has resulted in fragmentation of literature and confusion among research community. Bernett, Jermier, Lafferty (2006) in their review article titledcorporate reputation - the definitional landscape, identified three groups, researchers who understood corporate reputation as an asset, as a judgement (evaluative), or just a perception (information) held by various stakeholders. They differentiated and proposed relationships among the related constructs of corporate identity, corporate image, corporate reputation and corporate reputational capital. They found that corporate identity was understood as a perception of an organization held by their internal stakeholders (employees), whereas, corporate image was a perception of organizational held by external stakeholders, corporate reputation was an evaluative (positive or negative; good or bad) judgement of organizations held by all stakeholders, whereas reputation capital was meant to suggest the value of reputation in terms of financial benefits, this was held by economists, accountants and finance professionals. 
An organizational image in general, is the public opinion of a company. It includes all the experiences, impressions, beliefs, feelings and knowledge that people have about a firm. It contains invisible and intangible elements such as organizational, personnel, environmental policies, Ideals, beliefs, culture of country and location of company as well as its media report. Organizational image refers broadly to what members perceive, feel and think about their organizations.

According to Erdem (2013), Researchers have studied the concepts of organization credibility, reputation, identity, attractiveness, employer branding and image. All of these concepts have at one time or another, been treated synonymously. Of course, there are similarities, differences as well as interdependencies amongst the concepts.

\section{Research Methodology}

A systematic literature review approach comprises a systematic, explicit, and reproducible method to identify, appraise, and synthesize extant research. It gives an overview of prior research findings to identify similarities and differences. It deduces and links previous research in new ways or with an original perspective and to ascertain the reasons for conflicting findings. Thus it helps to identify the gap and determine the areas of future research (Booth et al.2011).

We first defined the topic and the corresponding key words. Existing recruitment related articles were tagged with the following key words: "recruitment", "employ*image," These search items were combined with keywords "organizational image" and "organizational attractiveness" as they are related constructs and are sometimes used synonymously. Since the corporate brand concept also relates to organizational image and attractiveness (Balmer 2000), the keyword "brand" was included in the search.

We then searched scientific databases such as ProQuest, JSTOR, google scholar, Emerald for corresponding titles, keywords and or abstract of articles that were published till 2019. Using the title and the abstract of the article, we determined whether an article was relevant. A total of 119 articles that matched the defined search terms in the title, abstract and /or keywords. We then filtered the articles using the following filters (Table 1\&2). Articles prior to 1999 were excluded. articles with less 20 citations have been excluded as a lower citation means that they do not exert a great amount of influence in the field. However this rule does not apply for articles published in 2018 and 2019 since they might be too new to have citations already. All duplicates were excluded and articles that were not adequately related to the concept were excluded.

Table 3 shows the most common definitions.

\section{Table 1: Table of Filter Criteria}

\begin{tabular}{|l|l|}
\hline Criteria & Description \\
\hline Period & $\begin{array}{l}\text { Articles published before 1999 } \\
\text { were eliminated }\end{array}$ \\
\hline Citations & $\begin{array}{l}\text { Articles with less than 20 } \\
\text { citations were excluded. } \\
\text { However this rule does not apply } \\
\text { for articles published in 2018 \& } \\
2019 \text { as these are too new for } \\
\text { having citations. }\end{array}$ \\
\hline Duplicates & $\begin{array}{l}\text { Articles that were duplicated due } \\
\text { to search from different } \\
\text { databases were excluded }\end{array}$ \\
\hline Research design & Empirical or conceptual \\
\hline
\end{tabular}

Table 2: Selection process

\begin{tabular}{|l|l|}
\hline E database & No. of Articles \\
\hline Google Scholar & 52 \\
\hline ProQuest & 34 \\
\hline JSTOR & 21 \\
\hline Emerald & 12 \\
\hline Total & $\mathbf{1 1 9}$ \\
\hline & \\
\hline Filter Criteria & 17 \\
\hline $\begin{array}{l}\text { No relation to concept of } \\
\text { OI \& OA rearly }\end{array}$ & 27 \\
\hline $\begin{array}{l}\text { No relation to recruitment related topic } \\
\text { rections }\end{array}$ & 07 \\
\hline Articles with < 20 citations & 32 \\
\hline Duplicates & $\mathbf{8 3}$ \\
\hline Total & $\mathbf{3 6}$ \\
\hline Final articles for review
\end{tabular}

Table 3: Definitions

\begin{tabular}{|c|c|}
\hline Definition & Author \\
\hline $\begin{array}{l}\text { "The set of beliefs that a } \\
\text { (potential) applicant holds about } \\
\text { the attributes of an } \\
\text { organization". }\end{array}$ & $\begin{array}{l}\text { Cable and Turban } \\
(2001)\end{array}$ \\
\hline $\begin{array}{l}\text { "Envisioned benefits that a } \\
\text { potential employee sees in } \\
\text { working for a specific } \\
\text { organization". }\end{array}$ & $\begin{array}{l}\text { Berthon } \\
(2005)\end{array}$ \\
\hline $\begin{array}{l}\text { "The degree to which an } \\
\text { individual would personally seek } \\
\text { a company as an employer". }\end{array}$ & $\begin{array}{l}\text { Newburry, } \\
\text { Gardberg } \quad \& \\
\text { Belkin }(2006)\end{array}$ \\
\hline $\begin{array}{l}\text { "An attitude or expressed } \\
\text { general positive affect toward an } \\
\text { organization, toward viewing the } \\
\text { organizational as a desirable } \\
\text { entity with which to initiate } \\
\text { some relationship". }\end{array}$ & $\begin{array}{l}\text { Aiman-Smith et al } \\
(2001)\end{array}$ \\
\hline $\begin{array}{l}\text { "Overall judgment of the } \\
\text { attractiveness of } \\
\text { joborganization". }\end{array}$ & $\begin{array}{l}\text { Chapman et al. } \\
(2005)\end{array}$ \\
\hline
\end{tabular}




\subsection{Theoretical frameworks}

Numerous theoretical lenses have been applied to examine organizational image and attractiveness in the context of recruitment. Most papers have clearly defined theoretical framework. Social identity theory, Signaling theory and Brand equity theory are commonly used in the various studies.

Social identity theory focuses on 'the group in the individual' and assumes that one part of the selfconcept is defined by our belonging to social groups (Tajfel and Turner, 1986). Social identity theory is built on three key cognitive components: social categorization, social identification, and social comparison. In recruitment literature, social identity theory has typically been used to provide the mediating mechanisms between organizational perceptions and applicant behaviors.

Lievens et al (2001) in their study of Belgian Army examined which factors relating to employer image and organizational identity, the company outsiders (applicants) as well as company insiders (employees) associate with a given employer. Their findings were consistent with the tenents of the social identity theory, in that applicants ascribe symbolic meaning and traits to organizations because these traits enable them to maintain their self- identity and to enhance their self-image.

Based in cognitive psychology, brand equity theory has commonly defined brand equity as the incremental value or effect of what is known about the brand on consumer response to the marketing of the brand (e.g. brand prominence, differentiation and associations). Colins \& Kanar (2013) integrated a brand equity perspective from marketing to propose that the extent to which applicant's recognition of and favorable impressions about the organization's brand influence their willing to apply for a job. Employer brand equity occurs when potential job applicants strongly associate the organization with favorable emotions and attributes (Collins \& Kanar, 2013).

Recruitment research has used signaling theory to suggest that job seekers experience information asymmetry about potential employers and use signals from the organization to make inferences about organizational attributes (Highhouse, etal 2005).

Allen and Mahto (2007), based on data from 814 student participants searching actual organization web sites support and extend signaling and brand equity theories by showing that professional, welldesigned web sites may help prospective applicants find the information they are most interested in and provide positive signals about the organization and its potential as an employer.

The review of literature based on the above theories and frameworks assume that applicants' form impression of organizations during the recruitment

\section{ISSN 2455-6378}

process. They further propose that these impressions can be influenced by recruitment information provided by the organization and thus the impressions formed influence their behavior and choice. Thus, it could be inferred that the image formed by individuals about an organization depends on the information each one has about the organization, the way the individual picked up the information, the personalized way of classifying the information, the insight of the connection between those pieces of information and others already stored in their memory and the unique way of accessing the information and retrieving the data from the mental models.

\section{Results and Discussion}

An analysis of the research articles under review, categorized under journals and methods is presented below.

\subsection{Categorized by Journal publication}

The Table 4 shows the results of the type of journals in which articles under review on organizational image and attractiveness were published. Majority of the articles $45 \%$ are published in journals related to psychology, $22 \%$ in organizational studies, $11 \%$ each in Marketing and General Management and rest in HRM \& others.

Table 4: Journal category

\begin{tabular}{|c|c|}
\hline Journal Category & Articles \\
\hline $\begin{array}{c}\text { Prganchology } \\
\text { studies }\end{array}$ & 16 \\
\hline Marketing & 08 \\
\hline Management & 04 \\
\hline $\begin{array}{c}\text { Human Resources } \\
\text { Mgmt. }\end{array}$ & 04 \\
\hline Others & 02 \\
\hline TOTAL & 02 \\
\hline
\end{tabular}

\subsection{Categorized by Research Methods employed}

An analysis of the papers under review, which were classified based on the theoretical framework viz; social identity theory, brand equity theory and signaling theory etc.; we find that over $95 \%$ were empirical in nature, further the purpose of research in organizational image and attractiveness in our sample is mostly explanatory. Explanatory research is the investigation of cause-effect relationships and is most often performed by means of an experiment. The research methods used in the papers under review mostly employed the experimental design and survey method. The surveys were mostly crosssectional, which leads us to infer that the concept of organizational image and attractiveness can be easily measured at a certain amount of time. We also find that the commonly discussed antecedents of 
organizational image and attractiveness were familiarity and differentiation of the firm

\section{Conclusions}

The aim of the present review was to systematically examine the literature in the field of organizational image and attractiveness in the context of early recruitment. The most salient feature of the current literature is the variety of terms, definitions and methods and theoretical frameworks used. Though still fragmented, this field of research has constantly grown over the last two decades.

From the 36 core papers, we find that, predominantly the articles employed either the theoretical base of the social identity theory, signaling theory or brand equity theory.

Based on the social identity theory, we can infer from the articles that the identity of an applicant influences the way in which the applicant, looks at the organizational image and attractiveness. From the signaling theory we can infer that applicants rarely possess complete information about a company, and thus, use the information available as signals of unobservable factors. From the brand equity perspective the impression created by the brand image influences the favorable or not so favorable disposition towards the organization.

Most of the articles under review were empirical in nature, survey and experimental design was the predominant methodology and design. Most of the surveys were cross-sectional; therefore we can infer that the concept of image and attractiveness can be measured at a certain moment in time instead of a longer period.

\section{References}

[1] Allen, D. G., Mahto, R. V., \& Otondo, R. F. (2007). Web-based recruitment: Effects of information, organizational brand, and attitudes toward a Web site on applicant attraction. Journal of Applied Psychology, 92(6), 16961708

[2] Barber AE, Recruiting Employees: Individual and Organizational Perspectives https://books.google.co.in/books

[3] Breaugh JA (2008) Employee recruitment: Current knowledge and important areas for future researchHuman Resource Management Review, Volume 18, Issue 3, September 2008, Pages 103-118

[4] Cable, D.M. and Graham, M.E. (2000), The determinants of job seekers' reputation perceptions. J. Organiz. Behav., 21: 929-947

[5] Cable, D. M., \& Yu, K. Y. T. (2006). Managing job seekers' organizational image beliefs: The
ISSN 2455-6378

role of media richness and media credibility. Journal of Applied Psychology, 91(4), 828-840.

[6] Cable, DM \& Turban DB (2001) Establishing the Dimensions, Sources and value of jobseekers' employer knowledge during recruitment, Research in Personnel and Human Resources Management, Volume 20, pages 115163.

[7] Cable, D.M. and Turban, D.B. (2003), The Value of Organizational Reputation in the Recruitment Context: A Brand-Equity Perspective. Journal of Applied Social Psychology, 33: 2244-2266.

[8] Chapman, D. S., Uggerslev, K. L., Carroll, S. A., Piasentin, K. A., \& Jones, D. A. (2005). Applicant Attraction to Organizations and Job Choice: A Meta-Analytic Review of the Correlates of Recruiting Outcomes. Journal of Applied Psychology, 90(5), 928-944.

[9] Collins, C. J., \& Stevens, C. K. (2002). The relationship between early recruitment-related activities and the application decisions of new labor-market entrants: A brand equity approach to recruitment. Journal of Applied Psychology, 87(6), 1121-1133.

[10] Collins, C.J. and Han, J. (2004), Exploring Applicant Pool Quantity and Quality: The Effects of Early Recruitment Practice Strategies, Corporate Advertising, and Firm Reputation. Personnel Psychology, 57: 685-717.

[11]Devendorf, S.A. and Highhouse, S. (2008), Applicant-employee similarity and attraction to an employer. Journal of Occupational and Organizational Psychology, 81: 607-617

[12]Dutton EJ, Dukerich JM and Celia V. Harquail (1994), Organizational Images and Member Identification, Administrative Science Quarterly , Vol. 39, No. 2 (Jun., 1994), pp. 239-263

[13] Ehrhart, K. H., \& Ziegert, J. C. (2005). Why Are Individuals Attracted to Organizations? Journal of Management, 31(6), 901-919

[14]Gioia DA, Majken Schultz, and Kevin G. Corley, 2000: Organizational Identity, Image, and Adaptive Instability. $A M R, 25,63-81$

[15] Gotsi, M. and Wilson, A.M. (2001), "Corporate reputation: seeking a definition", Corporate Communications: An International Journal, Vol. 6 No. 1, pp. 24-30

[16]Highhouse Et al (2007) , Social-identity functions of attraction to organizations, Organizational Behavior and Human Decision Processes, Volume 103, Issue 1, May 2007, Pages 134-146 
[17]Hsi-Peng Lu; Her-Ran Liou (2015) Impacts of Business Companies' Recruitment Advertisements, Publicity, Sponsorship, and Word-of-Mouth on Graduating Students' Job Pursuit Intentions.Journal of Accounting, Finance \& Management Strategy. Jun2015, Vol. 10 Issue 1, p115-146. 32p

[18] Kausel Etal (2011) Narrow personality traits and organizational attraction: Evidence for the complementary hypothesis, Organizational Behavior and Human Decision Processes, Volume 114, Issue 1,2011,Pages 3-14,

[19]Lange, D., Lee, P. M., \& Dai, Y. (2011). Organizational Reputation: A Review. Journal of Management, 37(1), 153-184.

[20]Lievens, F., Decaesteker, C., Coetsier, P. and Geirnaert, J. (2001), Organizational Attractiveness for prospective applicants: a person-organization fit perspective. Applied psychology, 50: 30-51.

[21]Lievens, F. and Highhouse,S. (2003), The Relation of instrumental and symbolic attributes to a company's attractiveness as an employer. Personnel Psychology, 56: 75-102.

[22]Lievens, F., Van Hoye, G. and Schreurs, B. (2005), Examining the relationship between employer knowledge dimensions and organizational attractiveness: An application in a military context. Journal of Occupational and Organizational Psychology, 78: 553-572.

[23]Lievens, F., Van Hoye, G. and Anseel, F. (2007), Organizational Identity and Employer Image: Towards a Unifying Framework*. British Journal of Management, 18: S45-S59

[24]Lyons, B.D. and Marler, J.H. (2011), "Got image? Examining organizational image in web recruitment", Journal of Managerial Psychology, Vol. 26 No. 1, pp. 58-76.

[25] Maxwell R \&Simon Knox (2009) Motivating employees to "live the brand": a comparative case study of employer brand attractiveness within the firm, Journal of Marketing Management ,Volume 25, 2009 - Issue 9-10:

[26] Newburry, W., Gardberg, N. \& Belkin, L. Organizational attractiveness is in the eye of the beholder: the interaction of demographic characteristics with foreignness. J Int Bus Stud37, 666-686 (2006).

[27]Pierre Berthon, Michael Ewing\&Li Lian Hah (2005), Captivating company: dimensions of attractiveness in employer branding, International Journal of Advertising , The Review of Marketing Communications Volume 24, 2005 - Issue 2, Pages 151-172 | Published online: 06 Jan 2015
ISSN 2455-6378

[28] Ployhart, R. E., Schmitt, N., \& Tippins, N. T. (2017). Solving the Supreme Problem: 100 years of selection and recruitment at the Journal of Applied Psychology. Journal of Applied Psychology, 102(3), 291-304

[29] Robert D. Gatewood, Mary A. Gowan, and Gary J. Lautenschlager, 1993: Corporate Image, Recruitment Image And Initial Job Choice Decisions. AMJ,36, 414-427

[30] Roberts, P.W. and Dowling, G.R. (2002), Corporate reputation and sustained superior financial performance. Strat. Mgmt. J.,

[31]Rynes, S.L. and Cable, D.M. (2003). Recruitment Research in the Twenty-First Century. In Handbook of Psychology, I.B. Weiner (Ed.)

[32] Thomas, K.M., Wise, P.G. Organizational Attractiveness and Individual Differences: Are Diverse Applicants Attracted by Different Factors?. Journal of Business and Psychology13, 375-390 (1999).

[33] Thorsteinson, T.J. and Highhouse, S. (2003), Effects of Goat Framing in Job Advertisements on Organizational Attractiveness1. Journal of Applied Social Psychology, 33: 2393-2412.

[34] Turban DB, Organizational Attractiveness as an Employer on College Campuses: An Examination of the Applicant Population, Journal of Vocational Behavior, Volume 58, Issue 2, April 2001, Pages 293-312

[35] Turban, D. B., Lau, C.-M., Ngo, H.-Y., Chow, I. H. S., \& Si, S. X. (2001). Organizational attractiveness of firms in the People's Republic of China: A person-organization fit perspective. Journal of Applied Psychology, 86(2), 194-206.

[36] Umphress, E. E., Smith-Crowe, K., Brief, A. P., Dietz, J., \& Watkins, M. B. (2007). When birds of a feather flock together and when they do not: Status composition, social dominance orientation, and organizational attractiveness. Journal of Applied Psychology, 92(2), 396-409

[37] Van Hoye, G. and Lievens, F. (2007), Social Influences on Organizational Attractiveness: Investigating If and When Word of Mouth Matters1. Journal of Applied Social Psychology, 37: 2024-2047.

[38] Van Hoye, G. and Saks, A.M. (2011), The Instrumental-Symbolic Framework: Organizational Image and Attractiveness of Potential Applicants and their Companions at a Job Fair. Applied Psychology, 60: 311-335

[39] Wilden Ralf, Gudergan Siegfried \& Ian Lings (2010) Employer branding: strategic 
implications for staff recruitment, Journal of Marketing Management, 26:1-2, 56-73,

[40] Williamson I.O, David P. Lepak, James King, The effect of company recruitment web site
ISSN 2455-6378

orientation on individuals' perceptions of organizational attractiveness, Journal of Vocational Behavior, Volume 63, Issue 2,2003,Pages 242-263 